\title{
Characterization of a Colostrum Replacer and a Colostrum Supplement Containing IgG Concentrate and Growth Factors
}

\author{
C. J. Hammer, ${ }^{1}$ J. D. Quigley, ${ }^{1}$ L. Ribeiro, ${ }^{1}$ and H. D. Tyler $^{2}$ \\ ${ }^{1}$ APC, Inc., Ames, IA 50010 \\ ${ }^{2}$ Department of Dairy Science, \\ lowa State University, Ames 50011
}

\section{ABSTRACT}

The objective of this study was to characterize absorption of colostrum replacer (CR) or supplement (CS) containing fractions of bovine plasma. Immunoglobulin concentrate (IGC) was prepared from bovine blood to a final purity of approximately $90 \%$ IgG. Blood was also processed to produce a fraction containing elevated concentrations of IGF-I and TGF- $\beta($ GF). Both IGC and GF were spray-dried and blended with other ingredients to produce CR (30\% IgG) or CS (15\% IgG) containing 0 or $5 \%$ GF. Holstein bull calves were assigned to one of five treatments: 1) Pooled colostrum (MC) $-1.9 \mathrm{~L}$ of pooled colostrum at 1 and $8 \mathrm{~h}$ of age to provide over $150 \mathrm{~g}$ of IgG; 2) Low supplement (LC) - 1.9 L of CS at 1 and $8 \mathrm{~h}$ of age to provide $150 \mathrm{~g}$ of IgG; 3 ) Low supplement + GF (LG) $-1.9 \mathrm{~L}$ of a CS with GF at 1 and $8 \mathrm{~h}$ of age to provide $150 \mathrm{~g}$ of IgG; 4) High supplement (HC) $-1.9 \mathrm{~L}$ of $\mathrm{CR}$ at $1 \mathrm{~h}$ of age to provide $150 \mathrm{~g}$ of $\mathrm{IgG}$ and $1.9 \mathrm{~L}$ of a commercial milk replacer (MR) at $8 \mathrm{~h}$ of age; and 5) High supplement + GF (HG) - 1.9 L of a CR with GF at $1 \mathrm{~h}$ of age to provide $150 \mathrm{~g}$ of $\mathrm{IgG}$ and $1.9 \mathrm{~L}$ of MR at $8 \mathrm{~h}$ of age. Apparent efficiency of IgG absorption was higher for calves fed $\mathrm{HC}$ and $\mathrm{HG}$ compared with those fed LC and LG and was lower for calves fed LG and HG compared with those fed LC and HC. IgG concentrations at $24 \mathrm{~h}$ were highest in calves fed MC compared with other calves and were higher in calves fed HC and HG compared to LC and LG. Calves fed LG and HG had lower IgG concentrations at $24 \mathrm{~h}$ of age compared with those fed LC and HC. These results indicate that $150 \mathrm{~g}$ of $\mathrm{IgG}$ provided in one dose soon after birth is superior to $150 \mathrm{~g}$ of IgG fed in two doses $7 \mathrm{~h}$ apart. Also, addition of a plasma fraction containing elevated concentrations of IGF-I and TGF- $\beta$ decreased IgG absorption in the neonatal calf.

(Key words: colostrum replacer, immunoglobulin G, calf)

\footnotetext{
Received July 15, 2003

Accepted September 10, 2003

Corresponding author: C. Hammer; carolyn.hammer@ amerprotcorp.com.
}

Abbreviation key: AEA = apparent efficiency of IgG absorption, $\mathbf{C R}=$ colostrum replacer, $\mathbf{C S}=$ colostrum supplement, FPT = failure of passive transfer, $\mathbf{G F}=$ serum fraction with elevated IGF-I and TGF- $\beta, \mathbf{H C}=$ high supplement; HG = high supplement plus GF; IGC = immunoglobulin concentrate, IGF-I = insulin like growth factor-I, LC = low supplement; LG - low supplement plus GF, $\mathbf{M C}=$ pooled colostrum; $\mathbf{M R}=$ milk replacer, $\mathbf{T G F}-\boldsymbol{\beta}=$ transforming growth factor $\beta$.

\section{INTRODUCTION}

Colostrum is vital to the health and survival of the neonatal calf, and $18 \%$ of dairy cows provide colostrum yields containing less than $100 \mathrm{~g}$ of IgG, the most commonly recommended amount to prevent failure of passive transfer (FPT) (Levieux and Ollier, 1999). Colostrum-deprived calves are 50 to 75 times more likely to die before $21 \mathrm{~d}$ of age than colostrum-fed calves, with most deaths occurring during the first week of life (Smith and Little, 1922; Crowley et al., 1994; Wells et al., 1996). Therefore, colostrum supplements (CS) and colostrum replacers (CR) can be provided when colostrum is either of poor quality or unavailable. Colostrum supplements are preparations intended to provide $<100$ $\mathrm{g}$ of IgG/dose and are not formulated to replace colostrum. On the other hand, colostrum replacers contain $>100 \mathrm{~g}$ of IgG/dose and usually provide additional nutrients required by the calf (Quigley et al., 2002).

The ability to absorb IgG intact across the intestinal epithelium diminishes rapidly after birth and ceases by approximately $24 \mathrm{~h}$ of age (Stott et al., 1979). Current management practices often include 2 feedings of colostrum that are provided soon after birth and again 12 $\mathrm{h}$ later. When the mass of IgG is held constant, greater amounts are absorbed when the concentration in the colostrum is higher-for example, $1 \mathrm{~L}$ of colostrum containing $100 \mathrm{mg}$ of $\mathrm{IgG} / \mathrm{mL}$ is absorbed with greater efficiency than $2 \mathrm{~L}$ of colostrum containing $50 \mathrm{mg}$ of IgG/mL (Stott and Fellah, 1983). Studies in calves comparing colostrum that provides a similar mass of IgG fed in 1 or divided into 2 feedings are limited (Hopkins 
and Quigley, 1997; Morin et al., 1997), and similar studies using CS or CR have not been done.

Colostrum not only provides passive immunity for the newborn calf, but it can also have profound effects on the development of the neonatal intestine. Villous circumference, area, height, and height/crypt depth ratio in the duodenum are higher for calves fed colostrum compared with colostrum-deprived calves (Buhler et al., 1998; Blattler et al., 2001). Calves fed colostrum also have higher plasma xylose concentrations after oral administration of xylose compared with calves fed milk replacer (MR), suggesting enhanced absorptive capabilities in colostrum fed animals (Hammon and Blum, 1997; Kuhne et al., 2000).

Colostrum contains elevated levels of many growth factors, including insulin-like growth factor-I (IGF-I), which has been shown to enhance intestinal development in piglets (Oda et al., 1989; Lee et al., 1995; Burrin et al., 1996). Rauprich et al. (2000) reported increased xylose uptake in calves fed colostrum compared with calves fed formula similar to colostrum but containing only $15 \%$ of the IGF-I content of colostrum. In contrast, Buhler et al. (1998) found no enhancement of gut development in colostrum-fed calves after oral or subcutaneous injection of IGF-I. The effect of growth factors on immunoglobulin absorption in neonatal calves has not been characterized.

Therefore, the objectives of this study were twofold: 1) to characterize the absorption of colostrum replacer (CR) or supplement (CS) containing a fraction of bovine plasma with elevated concentrations of IGF-I and transforming growth factor- $\beta$ (TGF- $\beta$ ) and 2 ) to characterize the absorption of a similar mass of IgG fed in 1 feeding or divided into 2 feedings.

\section{MATERIALS AND METHODS}

\section{Diet Formulation}

Bovine blood was collected from animals in an USDA inspected abattoir. Animals were inspected and approved for human consumption followed by stunning with captive bolt and then exsanguinated. Blood was collected into a stainless steel container treated with anticoagulant. Plasma was separated by centrifugation, chilled (approximately $4^{\circ} \mathrm{C}$ ) and transported to the laboratory. Immunoglobulin $\mathrm{G}$ was fractionated from plasma using a proprietary precipitation procedure. The percentage of IgG in the resulting immunoglobulin concentrate (IGC) was 9-fold higher than in normal bovine plasma. Bovine plasma was also processed to produce a fraction containing elevated concentrations of IGF- 1 and TGF- $\beta(\mathbf{G F})$. Both IGC and GF were spray-
Table 1. Formulation of experimental colostrum supplements (CS) and colostrum replacers (CR).

\begin{tabular}{lllll}
\hline Ingredient (\% of formula) & $\mathrm{LC}^{1}$ & $\mathrm{LG}$ & $\mathrm{HC}$ & $\mathrm{HG}$ \\
\hline Ig concentrate $^{2}$ & 16.67 & 16.67 & 33.33 & 33.33 \\
Dry fat blend $^{2}$ & 35 & 35 & 35 & 35 \\
Whey protein concentrate $(75 \%)$ & 10 & 5 & 5 & 0 \\
Growth factor fraction & 0 & 5 & 0 & 5 \\
Whey & 35.83 & 35.83 & 24.17 & 24.17 \\
Premix $^{3}$ & 2.5 & 2.5 & 2.5 & 2.5 \\
\hline
\end{tabular}

${ }^{1} \mathrm{LC}=1.9 \mathrm{~L}$ of CS at 1 and $8 \mathrm{~h} ; \mathrm{LG}=1.9 \mathrm{~L}$ of CS with GF at 1 and $8 \mathrm{~h} ; \mathrm{HC}=1.9 \mathrm{~L}$ of $\mathrm{CR}$ at $1 \mathrm{~h}$ and $1.9 \mathrm{~L}$ of $\mathrm{MR}$ at $8 \mathrm{~h} ; \mathrm{HG}=1.9 \mathrm{~L}$ of $\mathrm{CR}$ with $\mathrm{GF}$ at $1 \mathrm{~h}$ and MR at $8 \mathrm{~h}$.

${ }^{2}$ Dry fat blend containing $7 \%$ crude protein and $60 \%$ crude fat.

${ }^{3}$ Premix contains vitamins and minerals to meet 1989 NRC requirements.

dried and blended with other ingredients (Table 1) to produce CR (30\% IgG) or CS (15\% IgG) and either containing 0 or $5 \% \mathrm{GF}$. The CS was formulated to provide $75 \mathrm{~g}$ of IgG/500 $\mathrm{g}$ of dose; 2 doses were fed to provide a total of $150 \mathrm{~g}$ of IgG. The $\mathrm{CR}$ was formulated to provide $150 \mathrm{~g}$ of $\mathrm{IgG} / 500 \mathrm{~g}$ of dose; 1 dose was fed to provide 150 $\mathrm{g}$ of IgG.

Maternal colostrum was collected soon after calving and pooled into 5-gallon buckets per standard management protocol on this dairy. A large number of calving cows ensured that pools were fed within $4 \mathrm{~h}$ of collection. Samples of each colostrum pool and from each experimental diet were analyzed for IgG content (Etzel et al., 1997). Experimental diets were analyzed for proximate nutrients according to AOAC procedures at a commercial facility (Silliker Inc., Cedar Rapids, IA). A sample of GF was analyzed for IGF-I and TGF- $\beta$ concentrations using commerically available ELISA kits (R \& D Systems, Minneapolis, MN; Promega, Madison, WI).

\section{Experimental Procedure}

Holstein bull calves $(n=40)$ were removed from their dams immediately after birth and assigned to 1 of 5 treatments: 1) Pooled colostrum (MC) - 1.9 L of pooled colostrum at 1 and $8 \mathrm{~h}$ of age to provide over $150 \mathrm{~g}$ of IgG; 2) Low supplement (LC) -1.9 L of CS at 1 and 8 h of age to provide $150 \mathrm{~g}$ of IgG; 3) Low supplement + GF (LG) - 1.9 L of a CS with GF at 1 and $8 \mathrm{~h}$ of age to provide $150 \mathrm{~g}$ of IgG; 4) High supplement (HC) - 1.9 $\mathrm{L}$ of CR at $1 \mathrm{~h}$ of age to provide $150 \mathrm{~g}$ of IgG and $1.9 \mathrm{~L}$ of MR at $8 \mathrm{~h}$ of age; and 5) High supplement + GF (HG) $-1.9 \mathrm{~L}$ of a CR with GF at $1 \mathrm{~h}$ of age to provide $150 \mathrm{~g}$ of IgG and $1.9 \mathrm{~L}$ of MR at $8 \mathrm{~h}$ of age. Experimental diets were reconstituted in water and mixed in a household blender until well blended. The mixture was then poured into a nipple bottle and offered to the calf. Pooled colostrum was also offered to the calf in a nipple bottle. 
Table 2. Composition of experimental colostrum supplements, colostrum replacers, and milk replacer.

\begin{tabular}{lrrrrr}
\hline Item $^{1}, \%$ & LC $^{2}$ & LG & HC & HG & $\mathrm{MR}^{3}$ \\
\hline DM & 96.8 & 93.6 & 95.5 & 93.6 & 97.1 \\
CP & 31.3 & 32.1 & 40.3 & 41.5 & 21.3 \\
Ash & 5.7 & 5.5 & 4.8 & 4.8 & 7.1 \\
Fat & 19.8 & 23.6 & 23.1 & 23.8 & 23.6 \\
\hline
\end{tabular}

${ }^{1}$ Items are on a DM basis, except for DM.

${ }^{2} \mathrm{LC}=1.9 \mathrm{~L}$ of $\mathrm{CS}$ at 1 and $8 \mathrm{~h} ; \mathrm{LG}=1.9 \mathrm{~L}$ of $\mathrm{CS}$ with $\mathrm{GF}$ at 1 and $8 \mathrm{~h} ; \mathrm{HC}=1.9 \mathrm{~L}$ of $\mathrm{CR}$ at $1 \mathrm{~h}$ and 1.9

$\mathrm{L}$ of $\mathrm{MR}$ at $8 \mathrm{~h} ; \mathrm{HG}=1.9 \mathrm{~L}$ of $\mathrm{CR}$ with $\mathrm{GF}$ at $1 \mathrm{~h}$ and $\mathrm{MR}$ at $8 \mathrm{~h}$.

${ }^{3} \mathrm{MR}=$ commercial milk replacer provided to calves in treatments $\mathrm{HC}$ and $\mathrm{HG}$ at $8 \mathrm{~h}$ of age.

Amounts not voluntarily consumed were provided via an esophageal feeder.

At 0 and $24 \mathrm{~h}$ of age, blood was collected from all calves by jugular venipuncture into evacuated tubes containing EDTA. A small sample of blood was used for hematocrit determination using a microhematocrit centrifuge. Plasma was collected by centrifugation and total protein was determined with a handheld refractometer (Schuco Clinical Refractometer). Remaining plasma was frozen $\left(-20^{\circ} \mathrm{C}\right)$ for later determination of IgG by turbidimetric immunoassay (Etzel et al., 1997).

\section{Xylose Absorption}

Five calves each from the treatment groups HG and $\mathrm{MC}$, and 6 calves from group $\mathrm{HC}$ were administered an oral xylose solution ( $0.5 \mathrm{~g}$ of $d$-xylose $/ \mathrm{kg} \mathrm{BW}$ ) at $2 \mathrm{~d}$ of age approximately $4 \mathrm{~h}$ after the morning meal. Blood samples were obtained from each calf via jugular venipuncture prior to xylose administration and again at 2 $\mathrm{h}$ after xylose ingestion. Plasma was collected by centrifugation and frozen $\left(-20^{\circ} \mathrm{C}\right)$ for later spectrophotometric analysis (Merritt and Duelly, 1983).

\section{Statistical Analysis}

Experimental data were analyzed using the general linear models procedure of SAS (1996). Orthogonal contrasts were used to test differences between $\mathrm{MC}$ and $\mathrm{CR}$, low IgG dose and high IgG dose, 0 and 5\% GF addition, and high IgG dose with and without GF addition. Chi-square analysis was used to determine differences in rates of FPT between treatment groups. Significance was declared at $P<0.05$ unless otherwise noted.

\section{RESULTS AND DISCUSSION}

Composition of the experimental CS and CR, as well as the MR provided to calves on treatment $\mathrm{HC}$ and $\mathrm{HG}$, is provided in Table 2. It should be noted that CS are usually referred to as preparations intended to provide $<100 \mathrm{~g}$ of IgG/dose and not formulated to replace colos- trum. However, in this study, LC and LG (serving as CS) provided $<100 \mathrm{~g}$ of IgG/dose, but also contained additional energy and nutrients, allowing it to replace colostrum. Crude protein percentage was slightly higher in HC and HG diets; however, total protein consumed was similar between treatments since calves on treatment $\mathrm{HC}$ and $\mathrm{HG}$ were fed MR for the second feeding at $8 \mathrm{~h}$ of age. The percentage of fat was lower in the LC diet, even though the diet was formulated to contain the same percentage of dry fat blend as other treatment diets. This result was unexpected and may be due to variability in the laboratory assay. Composition of GF is in Table 3.

Four calves were delivered with extreme difficulty and did not survive until the 24-h blood sample; data from these calves were excluded from analyses. Mean BW of calves did not differ among treatments (Table 4). Frequency of feeding via esophageal feeder also did not differ among treatments.

Least squares means for hematocrit at time 0 tended to be different between groups receiving 0 and $5 \% \mathrm{GF}$ and between the HG and LG (Table 4). For this reason, hematocrit at time 0 was included as a covariable in the statistical analysis. At $24 \mathrm{~h}$, hematocrit were higher in calves fed HC and HG compared to LC and LG and in calves fed HG compared to LG. Total plasma protein at time 0 was unaffected by treatment (Table 4). However, at $24 \mathrm{~h}$, calves fed MC had higher total plasma

Table 3. Composition and analysis of serum fraction GF.

\begin{tabular}{lc}
\hline Item $^{1}$ & Value \\
\hline $\mathrm{DM}^{2}, \%$ & 96.6 \\
TP, \% & 93.24 \\
Albumin, \% & 56.64 \\
IgG, \% & 19.7 \\
Ash, \% & 0.61 \\
TGF- $\beta_{1}$, ng/g & 765 \\
TGF- $\beta_{2}$, ng/g & 9 \\
IGF-1, ng/g & 1368 \\
\hline
\end{tabular}

\footnotetext{
${ }^{1}$ Items are on a DM basis, except for DM.

${ }^{2} \mathrm{DM}=$ dry matter; $\mathrm{TP}=$ total protein; IgG = immunoglobulin $\mathrm{G}$; TGF- $\beta=$ transforming growth factor beta; IGF-I = insulin like growth factor I.
} 
Table 4. Least squares means of treatment parameters for calves fed LC, LG, HC, HG, and MC.

\begin{tabular}{|c|c|c|c|c|c|c|c|c|c|c|}
\hline \multirow[b]{2}{*}{ Item } & \multicolumn{5}{|c|}{ Treatment ${ }^{1}$} & \multirow[b]{2}{*}{$\mathrm{SE}$} & \multicolumn{4}{|c|}{ Contrasts $^{2}$} \\
\hline & $\mathrm{MC}$ & $\mathrm{LC}$ & LG & $\mathrm{HC}$ & HG & & 1 & 2 & 3 & 4 \\
\hline No. calves & 7 & 7 & 7 & 8 & 7 & - & - & - & - & - \\
\hline $\mathrm{BW}, \mathrm{kg}$ & 49.4 & 47.3 & 45.4 & 45.2 & 49.2 & 1.8 & $\mathrm{NS}^{3}$ & NS & NS & NS \\
\hline IgG intake, $g$ & 282 & 150 & 150 & 150 & 150 & 9 & 0.001 & NS & NS & NS \\
\hline Protein intake, $\mathrm{g}$ & 494 & 303 & 302 & 296 & 299 & 13 & 0.001 & NS & NS & NS \\
\hline \multicolumn{11}{|l|}{ Plasma IgG, g/L } \\
\hline $0 \mathrm{~h}$ & 0 & 0 & 0 & 0 & 0 & 0 & NS & NS & NS & $\mathrm{NS}$ \\
\hline $24 \mathrm{~h}$ & 18.1 & 10.6 & 9.1 & 13.0 & 10.3 & 0.9 & 0.001 & 0.05 & 0.02 & NS \\
\hline Change 0 to $24 \mathrm{~h}$ & 18.1 & 10.6 & 9.1 & 13.0 & 10.3 & 0.9 & 0.001 & 0.05 & 0.02 & $\mathrm{NS}$ \\
\hline $\mathrm{AEA}^{4} \%$ & 29 & 30 & 24 & 35 & 30 & 2 & NS & 0.02 & 0.03 & 0.07 \\
\hline $\mathrm{FPT}^{5}, \%$ & 0 & 42 & 57 & 0 & 28 & 14 & 0.06 & 0.02 & NS & NS \\
\hline \multicolumn{11}{|l|}{ Plasma protein, g/L } \\
\hline $0 \mathrm{~h}$ & 4.75 & 4.62 & 4.37 & 4.57 & 4.51 & 0.15 & NS & NS & NS & NS \\
\hline $24 \mathrm{~h}$ & 6.12 & 5.02 & 5.20 & 5.24 & 4.91 & 0.17 & 0.001 & NS & NS & $\mathrm{NS}$ \\
\hline Change 0 to $24 \mathrm{~h}$ & 1.37 & 0.40 & 0.86 & 0.61 & 0.40 & 0.15 & 0.001 & NS & NS & 0.06 \\
\hline \multicolumn{11}{|l|}{ Hematocrit, \% } \\
\hline $0 \mathrm{~h}$ & 40.14 & 42.57 & 33.14 & 37.62 & 39.28 & 2.62 & NS & NS & 0.09 & 0.06 \\
\hline $24 \mathrm{~h}^{6}$ & 33.19 & 33.65 & 29.85 & 34.76 & 36.21 & 1.58 & NS & 0.02 & NS & 0.01 \\
\hline Change 0 to $24 \mathrm{~h}^{6}$ & -5.12 & -4.66 & -8.45 & -3.55 & -2.10 & 1.58 & NS & 0.02 & NS & 0.01 \\
\hline
\end{tabular}

${ }^{1} \mathrm{MC}=1.9 \mathrm{~L}$ of maternal colostrum at 1 and $8 \mathrm{~h} ; \mathrm{LC}=1.9 \mathrm{~L}$ of $\mathrm{CS}$ at 1 and $8 \mathrm{~h} ; \mathrm{LG}=1.9 \mathrm{~L}$ of CS with $\mathrm{GF}$ at 1 and $8 \mathrm{~h} ; \mathrm{HC}=1.9 \mathrm{~L}$ of $\mathrm{CR}$ at $1 \mathrm{~h}$ and $1.9 \mathrm{~L}$ of $\mathrm{MR}$ at $8 \mathrm{~h} ; \mathrm{HG}=1.9 \mathrm{~L}$ of $\mathrm{CR}$ with $\mathrm{GF}$ at $1 \mathrm{~h}$ and $\mathrm{MR}$ at $8 \mathrm{~h}$.

${ }^{2}$ Contrasts: $1=\mathrm{MC}$ vs. CR; $2=$ Low vs. High; $3=5 \%$ GF vs. $0 \%$ GF; $4=$ LG vs. HG.

${ }^{3} P>0.10$.

${ }^{4}$ Apparent efficiency of absorption, calculated as plasma $\operatorname{IgG}(\mathrm{g} / \mathrm{L}) \times \mathrm{BW}(\mathrm{kg}) \times 9 \% / \mathrm{IgG}$ intake $(\mathrm{g})$.

${ }^{5}$ Failure of passive transfer $(\mathrm{IgG}<10 \mathrm{~g} / \mathrm{L})$.

${ }^{6}$ Covariate adjusted.

protein compared with calves on the other treatments. This is explained by the increased mass of protein fed to these calves.

Concentrations of IgG (Table 4) were highest at 24 $\mathrm{h}$ of age in calves fed MC compared with calves in the other four treatment groups, which is easily attributable to the increased IgG intake of calves in this treatment group. Total IgG intake averaged $282 \mathrm{~g}$ (range = 150 to $543 \mathrm{~g}$ IgG) for calves fed MC and $150 \mathrm{~g}$ for calves fed all other treatments. The GF fraction contributed an additional $4 \mathrm{~g}$ of IgG to calves in treatments LG and HG. The whey protein concentrate used in the diet formulations also contains an average of $5 \%$ IgG (internal data, Proliant, Ames, IA). At the highest inclusion rate of $10 \%$, an additional $2.5 \mathrm{~g}$ of IgG would be contributed. Apparent effeciency of absorption for whey protein concentrate supplements has been reported to range from 20 to $27 \%$; thus the contribution to circulating plasma IgG in the calf would be negligible (Mee et al., 1996; Arthington et al., 2000). Whey itself contains $<1$ $\mathrm{g} / \mathrm{L}$ of $\mathrm{IgG}$, and again could have contributed minimal amounts of IgG (Levieux and Ollier, 1999).

Concentrations of $\mathrm{IgG}$ were higher at $24 \mathrm{~h}$ of age in calves fed HC and HG compared to LC and LG, even though the total IgG intake was equal between all groups. Apparent efficiency of IgG absorption (AEA) (Table 4) was also higher in calves fed $\mathrm{HC}$ and $\mathrm{HG}$ compared with those fed LC and LG. These results contradict previous findings that show no difference in serum IgG concentrations and similar AEA after feeding calves a large amount at birth or the same amount divided into 2 or 3 feedings (Hopkins and Quigley, 1997; Morin et al., 1997). However, comparisons in previous studies were based on feeding low or high quality maternal colostrum, whereas calves in the current study received similarly formulated CS or CR. The AEA for CR derived from bovine Ig concentrate has been shown to be higher when fed once compared to feeding twice after birth $8 \mathrm{~h}$ apart (Quigley et al., 2001). The values for AEA observed in this trial are similar to those previously reported for CS and CR prepared from bovine plasma (Quigley et al., 2002). However, IgG concentrations were higher in calves fed the CS and CR formulations than those previously reported by Quigley et al. (1998) for calves receiving $150 \mathrm{~g}$ of IgG obtained from bovine serum.

Calves fed LG and HG also had lower IgG concentrations at $24 \mathrm{~h}$ of age and lower AEA compared with those fed LC and HC, suggesting that addition of GF to the $\mathrm{CS}$ and CR formulation negatively influenced IgG absorption. Concentrations of TGF- $\beta$ and IGF-I, although concentrated in the serum fraction, were still well below the concentrations found in bovine colostrum. Values for IGF-I and TGF- $\beta_{1}$ in cow colostrum range from 203 
Table 5. Least squares means for xylose absorption in calves fed $\mathrm{HG}, \mathrm{HC}$, and MC.

\begin{tabular}{|c|c|c|c|c|c|c|}
\hline \multirow[b]{2}{*}{ Item } & \multicolumn{3}{|c|}{ Treatment $^{1}$} & \multirow[b]{2}{*}{ SE } & \multicolumn{2}{|c|}{ Contrasts $^{2}$} \\
\hline & $\mathrm{MC}$ & $\mathrm{HC}$ & HG & & 1 & 2 \\
\hline No. calve & 5 & 6 & 5 & - & - & - \\
\hline Xylose absorption, & & & & & & \\
\hline $0 \mathrm{~h}$ & 16.56 & 15.22 & 15.89 & 0.56 & $\mathrm{NS}^{3}$ & NS \\
\hline $2 \mathrm{~h}$ & 71.55 & 55.97 & 60.76 & 9.0 & NS & NS \\
\hline Change $0-2 \mathrm{~h}$ & 54.98 & 40.74 & 44.87 & 8.9 & NS & NS \\
\hline
\end{tabular}

${ }^{1} \mathrm{MC}=1.9 \mathrm{~L}$ of maternal colostrum at 1 and $8 \mathrm{~h} ; \mathrm{HC}=1.9 \mathrm{~L}$ of $\mathrm{CR}$ at $1 \mathrm{~h}$ and $1.9 \mathrm{~L}$ of MR at $8 \mathrm{~h} ; \mathrm{HG}=1.9 \mathrm{~L}$ of $\mathrm{CR}$ with $\mathrm{GF}$ at $1 \mathrm{~h}$ and MR at $8 \mathrm{~h}$.

${ }^{2}$ Contrasts: $1=\mathrm{MC}$ vs. $\mathrm{CR} ; 2=5 \% \mathrm{GF}$ vs. $0 \% \mathrm{GF}$.

${ }^{3} P>0.10$.

to $1850 \mathrm{ng} / \mathrm{mL}$ and from 12.4 to $42.6 \mathrm{ng} / \mathrm{mL}$, respectively (Hadorn et al., 1997; Ginjala and Pakkanen, 1998). With the 5\% GF inclusion used in the current study, calves received $18 \mathrm{ng} / \mathrm{mL}$ of IGF-I and $10 \mathrm{ng} / \mathrm{mL}$ of TGF$\beta\left(0.12 \mathrm{ng} / \mathrm{mL}\right.$ of TGF- $\beta_{1} ; 10.01 \mathrm{ng} / \mathrm{mL}$ of TGF- $\left.\beta_{2}\right)$ per 500 -g dose. Roffler et al. (2003) fed a bovine colostral extract to calves that also contained low levels of IGFI and reported increases in intestinal villus circumference and villus height. These researchers also reported decreased xylose absorption in calves fed the colostral extract and hypothesized that these calves had normal intestinal maturation but reduced absorptive capacity.

Preadministration xylose concentrations (Table 5) were slightly higher than those previously reported. Others have reported preadministration xylose concentrations ranging from 7 to $13 \mathrm{mg} / \mathrm{dL}$ in 7 -d-old calves fed colostrum, whole milk, or milk replacer (Seegraber and Morrill, 1979; Kuhne et al., 2000). Hammon and Blum (1997) reported even lower concentrations of 4 to $5 \mathrm{mg} / \mathrm{dL}$ in 5 -d-old calves. Higher values observed in calves from the current study may be related to the different methods used to measure xylose, or the younger age of these calves.

Postadministration xylose samples were obtained 2 $\mathrm{h}$ after xylose administration and were not different among treatments. Peak xylose values are obtained 2 to $2.5 \mathrm{~h}$ after administration of xylose in fasted calves (Seegraber and Morrill, 1979); however, peak values are reached later in calves fed xylose with the morning meal (Kuhne et al., 2000; Rauprich et al., 2000). Previously reported peak xylose values in calves fed similar amounts of xylose average from 42 to $56 \mathrm{mg} / \mathrm{dL}$ over the first 5 wk of life, and values were not different for fasted and nonfasted calves (Seegraber and Morrill, 1979; Kuhne et al., 2000). Although postadministration xylose concentrations were higher in this study, changes in xylose between pre- and postadministration concentrations were similar to previously reported values (Seegraber and Morrill, 1979).
Previous studies report plasma xylose concentrations are greater after administration of xylose in colostrumfed calves compared to calves fed MR (Hammon and Blum, 1997; Kuhne et al., 2000). In the current study, calves were fed CR at one feeding and MR at the second, compared with previous trials in which calves were fed MR only. No difference in xylose absorption would be expected since the CR was designed to substitute for maternal colostrum. Hammon and Blum also (1997) observed no difference in xylose absorption when calves were fed maternal colostrum at only the first feeding or for more than one feeding. The lack of difference in xylose absorption after addition of GF also supports previous reports that show no enhancement of gut development after oral administration of IGF-I (Buhler et al., 1998; Roffler et al., 2003).

As mentioned previously, Roffler et al. (2003) reported decreased xylose absorption in calves fed colostral extract. Xylose absorption was not different between calves fed either 0 or $5 \%$ GF in the current study; however, there were differences in IgG absorption suggesting a change in absorptive capacity or in IgG metabolism. Xylose is absorbed in a manner similar to glucose, utilizing carrier-facilitated transport (Csaky and Lassen, 1964). This is in contrast to IgG, which is absorbed nonselectively for approximately the first $24 \mathrm{~h}$ after birth (Brandon and Lascelles, 1971). It is possible that the addition of GF to the formulations resulted in increased maturation of the intestine, resulting in a loss of pinocytotic ability, but not affecting carrier-mediated monosaccharide absorption.

\section{CONCLUSIONS}

Newborn calves readily absorbed the IgG concentrate used in this study, and plasma IgG concentrations at $24 \mathrm{~h}$ of age were greater than $10 \mathrm{~g} / \mathrm{L}$ in 4 of the 5 treatment groups. Results from this study indicate that $150 \mathrm{~g}$ of IgG provided in 1 dose soon after birth provides superior levels of passive immunity when compared to $150 \mathrm{~g}$ of IgG fed in 2 doses $7 \mathrm{~h}$ apart. These data also suggest that addition of a fraction of bovine plasma containing elevated concentrations of IGF-I and TGF$\beta$ to the CS and CR formulation decreased IgG absorption in the neonatal calf. Further studies are needed to determine the biological mechanisms by which growth factors influence intestinal immunoglobulin absorption in the neonatal calf.

\section{REFERENCES}

Arthington, J. D., M. B. Cattell, and J. D. Quigley. 2000. Effect of dietary IgG source (colostrum, serum, or milk-derived supplement) on the efficiency of $\mathrm{Ig}$ absorption in newborn Holstein calves. J. Dairy Sci. 83:1463-1467. 
Blattler, U., H. M. Hammon, C. Morel, C. Philipona, A. Rauprich, V. Rome, I. Le Hueron-Luron, P. Guilloteau, and J. W. Blum. 2001. Feeding colostrum, its composition and feeding duration variably modify proliferation and morphology of the intestine and digestive enzyme activities of neonatal calves. J. Nutr. 131:1256-1263.

Brandon, M. R., and A. K. Lascelles. 1971. Relative efficiency of absorption of IgG1, IgG2, IgA, and IgM in the newborn calf. Aust. J. Exp. Biol. Med. Sci. 49:629-633.

Buhler, C., H. Hammon, G. L. Rossi, and J. W. Blum. 1998. Small intestinal morphology in eight-day-old calves fed colostrum for different durations or only milk replacer and treated with long$\mathrm{R}^{3}$-insulin-like growth factor I and growth hormone. J. Anim. Sci. 76:758-765.

Burrin, D. G., T. J. Wester, T. A. Davis, S. Amick, and J. P. Heath. 1996. Orally administered IGF-I increases intestinal mucosal growth in formula-fed neonatal pigs. Am. J. Physiol. 270:R1085-R1091.

Crowley, M. L., L. J. Fisher, and B. D. Owen. 1994. Blood-derived immunoglobulins in milk replacer, or by injection, for improved performance of colostrum deprived neonatal calves. Anim. Feed Sci. Technol. 47:245-257.

Csaky, T. Z., and U. V. Lassen. 1964. Active intestinal transport of D-xylose. Biochim. Biophys. Acta 82:215-217.

Etzel, L. R., R. E. Strohbehn, and J. K. McVicker. 1997. Development of an automated turbidimetric immunoassay for quantification of bovine serum immunoglobulin G. Am. J. Vet. Res. 58:1201-1205.

Ginjala, V., and R. Pakkanen. 1998. Determination of transforming growth factor-beta 1 (TGF-beta 1) and insulin-like growth factor (IGF-1) in bovine colostrum samples. J. Immunoass. 19:195-207.

Hadorn, U., H. Hammon, R. M. Bruckmaier, and J. W. Blum. 1997. Delayed colostrum intake by one day has important effects on metabolic traits and on gastrointestinal and metabolic hormones in neonatal calves. J. Nutr. 127:2011-2023.

Hammon, H., and J. W. Blum. 1997. Prolonged colostrum feeding enhances xylose absorption in neonatal calves. J. Dairy Sci. 75:2915-2919.

Hopkins, B. A., and J. D. Quigley. 1997. Effect of method of colostrum feeding and colostrum supplementation on concentrations of immunoglobulin G in the serum of neonatal calves. J. Dairy Sci. 80:979-983.

Kuhne, S., H. M. Hammon, R. M. Bruckmaier, C. Morel, Y. Zbinden, and J. W. Blum. 2000. Growth performance, metabolic and endocrine traits, and absorptive capacity in neonatal calves fed either colostrum or milk replacer at two levels. J. Anim. Sci. 78:609-620.

Lee, C. Y., H. H. Head, C. R. Feinstein, J. Hayen, and F. A. Simmen. 1995. Endocrine changes and circulating insulin-like growth factors in newborn calves fed colostrum, milk or milk replacer. AJAS 8:51-58.

Levieux, D., and A. Ollier. 1999. Bovine immunoglobulin G, $\beta$-lactoglobulin, $\alpha$-lactoglobulin and serum albumin in colostrum and milk during the early post partum period. J. Dairy Res. 66:421-430.

Mee, J. F., K. J. O'Farrell, P. Reitsma, and R. Mehra. 1996. Effect of a whey protein concentrate used as a colostrum substitute or supplement on calf immunity, weight gain, and health. J. Dairy Sci. 79:886-894.

Merritt, A. M., and P. Duelly. 1983. Phloroglucinol microassay for plasma xylose in dogs and horses. Am. J. Vet. Res. 44:2184-2185.

Morin, D. E., G. C. McCoy, and W. L. Hurley. 1997. Effects of quality, quantity, and timing of colostrum feeding and addition of a dried colostrum supplement on immunoglobulin $\mathrm{G}_{1}$ absorption in Holstein bull calves. J. Dairy Sci. 80:747-753.

Oda, S., H. Satoh, T. Sugawara, N. Matsunaga, T. Kuhara, K. Katoh, Y. Shoji, A. Nihel, M. Ohta, and Y. Sasaki. 1989. Insulin-like growth factor-I, GH, insulin, and glucagon concentrations in bovine colostrum and in plasma of dairy cows and neonatal calves around parturition. Comp. Biochem. Physiol. 94A:805-808.

Quigley, J. D., D. L. Fike, M. N. Egerton, J. J. Drewry, and J. D. Arthington. 1998. Effects of a colostrum replacement product derived from serum on immunoglobulin $\mathrm{G}$ absorption by calves. J. Dairy Sci. 81:1936-1939.

Quigley, J. D., C. J. Kost, and T. M. Wolfe. 2002. Absorption of protein and IgG in calves fed a colostrum supplement or replacer. J. Dairy Sci. 85:1243-1248.

Quigley, J. D., R. E. Strohbehn, C. J. Kost, and M. M. O’Brien. 2001. Formulation of colostrum supplements, colostrum replacers and acquisition of passive immunity in neonatal calves. J. Dairy Sci. 84:2059-2065.

Rauprich, A. B. E., H. M. Hammon, and J. W. Blum. 2000. Effects of feeding colostrum and a formula with nutrient contents as colostrum on metabolic and endocrine traits in neonatal calves. Biol. Neonate 78:53-64.

Roffler, B., A. Fah, S. N. Sauter, H. M. Hammon, P. Gallmann, G. Brem, and J. W. Blum. 2003. Intestinal morphology, epithelial cell proliferation, and absorptive capacity in neonatal calves fed milk-born insulin-like growth factor-1 or a colostrum extract. J. Dairy Sci. 86:1979-1806.

SAS/STAT. 1996. SAS Inst., Inc. Cary. NC.

Seegraber, F. J., and J. L. Morrill. 1979. Effect of soy protein on intestinal absorptive ability of calves by the xylose absorption test. J. Dairy Sci. 62:972-977.

Smith, T., and R. B. Little. 1922. The significance of colostrum to the new-born calf. J. Exp. Med. 36:181-198.

Stott, G. H., and A. Fellah. 1983. Colostral immunoglobulin absorption linearly related to concentration for calves. J. Dairy Sci. 66:1319-1328.

Stott, G. H., D. B. Marx, B. E. Menefee, and G. T. Nightengale. 1979. Colostral immunoglobulin transfer in calves I. Period of absorption. J. Dairy Sci. 62:1632-1638.

Wells, S. J., D. A. Dargatz, and S. L. Ott. 1996. Factors associated with mortality to 21 days of life in dairy heifers in the United States. Prev. Vet. Med. 29:9-19. 